\title{
REALIZACE A VNÍMÁNí DŮLEŽITOSTI AKTIVIT SOCIÁLNÍHO PILÍŘE KONCEPTU CSR V ČESKÝCH PODNICÍCH
}

\section{Zdenka Hofbruckerová}

\section{Klíčová slova:}

společenská odpovědnost firem, sociální pilî́r, zaměstnanci, lidský kapitál

\section{Key words:}

Corporate Social Responsibility, social pillar, employees, human capital

\begin{abstract}
Abstrakt
Autorka se zaměřuje na pojetí sociálního pilíře společenské odpovědnosti firem. Hlavním cílem příspěvku je analyzovat přístup podnikatelských subjektů k aktivitám souvisejícím s uplatňováním sociálního pilî́re společenské odpovědnosti organizací. Sociální pilî́r společenské odpovědnosti organizací může působit jak na vnitřní prostředí organizace, tak i na vnější prostř̌edí organizace. Součástí analýzy je také vnímání důležitosti jednotlivých aktivit ze strany zaměstnanců.
\end{abstract}

\begin{abstract}
The author focuses on the concept of the social pillar of corporate social responsibility. The main aim of this paper is to analyze the approach to the business activities relating to the enforcement of the social pillar of corporate social responsibility. The social pillar of the corporate social responsibility can affect to internal environment and to external environmental of the organization. The part of the analysis is perception of the importance of activities by employees.
\end{abstract}

\section{Úvod}

Společenská odpovědnost organizací je dnes pro velké nadnárodní firmy již dávno známým pojmem. Uplatňování pilířu společenské odpovědnosti organizací se promítá ve všech oblastech fungování firmy. Jedním z pilîrů je sociální pilî̌r, zaměřený na aktivity dotýkající se vnitřního prostředí firmy (především zaměstnanců) a vnějšího prostředí firmy. Zejména oblast péče o zaměstnance je stále rozvíjenou oblastí. Firmy si dnes uvědomují, že spokojenost nebo nespokojenost zaměstnanců může v konečném důsledku výrazně ovlivnit kvalitu výrobku nebo poskytované služby. Rozvíjení zaměstnanců v podobě vzdělávání má přímý dopad na hodnotu podniku a její konkurenceschopnost. Působení aktivit vně podniku není pouhou propagací, ale především pomocí ostatním subjektům. Některou z aktivit sociálního pilíře dnes využívá většina firem, malých, středních i velkých. Jejich manažeři však mnohdy nevědí, že tyto programy spadají do konceptu společenské odpovědnosti a že jejich komunikace navenek může přispět ke zvyšování dobrého jména firmy.

\section{Pojetí sociálního pilířre CSR}

Společenská odpovědnost organizací neboli Corporate Social Responsibility (CSR) je kontinuální závazek podniků chovat se eticky, přispívat k ekonomickému růstu a zároveň se zasazovat o zlepšování kvality života zaměstnanců a jejich rodin, stejně jako lokální 
komunity a společnosti jako celku. ${ }^{1}$ Dle obnovené strategie EU pro CSR z října 2011 je pak nově definována společenská odpovědnost organizací jako „odpovědnost organizací za jejich dopady na společnost “. ${ }^{2}$

Společenská odpovědnost organizací znamená dobrovolný závazek firem nad rámec zákonných povinností chovat se v rámci svého podnikání odpovědně ke svým zaměstnancům, k prostředí ve kterém podnikají i společnosti a regionu ve kterém působí. Zahrnuje současně myšlenky etiky v podnikání.

Společenská odpovědnost organizací je velmi obsáhlý pojem zahrnující celou řadu aktivit, ty se dají členit do ucelených oblastí CSR.

CSR je koncept opírající se o tzv. trři pilírre - ekonomický, sociální a environmentální. Tyto tři pilî̌re korespondují s třemi charakteristikami, tzv. triple-bottom-line, neboli třemi „Pé““:

- Profit - zisk (ekonomická oblast)

- People - lidé (sociální oblast)

- Planet - planeta (environmentální oblast)

Co se týče ekonomické oblasti, od firmy je očekáváno transparentní podnikání a pozitivní vztahy s investory, zákazníky, dodavateli a dalšími obchodními partnery. Součástí tohoto pilî́re jsou i dopady na ekonomiku na místní, národní i globální úrovni, které mohou být posuzovány dle dopadů na zaměstnanost nebo boje proti korupci. V sociální oblasti je odpovědné chování organizace zaměřeno na př́stup k zaměstnancům, podporu okolní komunity a vztahy se zainteresovanými skupinami. Dochází k pozitivnímu ovlivňování životní úrovně, zdraví, bezpečnosti, vzdělávání a kulturního rozvoje občanů. Do tohoto pilî́re se řadí i charitativní aktivity a zaměření na sociálně slabší skupiny. Environmentální oblast zahrnuje uvědomění organizace dopadů své činnosti na prostředí kolem sebe, na ovzduší, vodní zdroje, půdu a ekosystém. Podnikatelská činnost by měla být vykonávána tak, aby chránila přírodní zdroje a co nejméně zatěžovala životní prostředí.

Článek je zaměřen zejména na aktivity sociálního pilíře. Tyto aktivity rozdělujeme na ty, které ovlivňují vnitřní prostř̌edí organizace a ty, které jsou směřovány ven z organizace, tedy na vnější prostředí.

Aktivity sociálního pilî́re CSR zaměřené na vnitřní prostředí organizace zahrnujî:

- vysokou úroveň zajištění zdraví a bezpečnosti zaměstnanců

- vysokou úroveň péče o lidské zdroje (rozvoj a vzdělávání)

- podpora pracovníků a vyváženost mezi pracovním a osobním životem

- zamezení diskriminace všeho druhu a zajištění rovných př́íležitostí

- péči o další zaměstnatelnost zaměstnanců v případě propuštění

- dodržování pracovních standardů

- zajištění dobrého pracovního prostředí

\footnotetext{
${ }^{1}$ PAVLÍK, M., BĚLČÍK, M. Společenská odpovědnost organizace. CSR v praxi a jak s ním dál. Praha: Grada Publishing, 2010, s. 19. ISBN 978-80-247-3157-5.

${ }^{2}$ Communication from the Commission to the European Parliament, the Council, the European Economic and Social Committee and the Committee of the Regions. Brusel: European Commission, 2011. s. 6

${ }^{3}$ PAVLÍK, M., BĚLČÍK, M. Společenská odpovědnost organizace. CSR v praxi a jak s ním dál. Praha: Grada Publishing, 2010, s. 25. ISBN 978-80-247-3157-5.

${ }^{4}$ HERCIK, P. Společenská odpovědnost organizací v kontextu komplexní podnikové strategie. Dizertační práce Zlín: UTB, 2011, s. 26.
} 
Dotčenými zainteresovanými stranami ekonomických aktivit jsou:

- zaměstnanci

- odbory

Aktivity sociálního pilíře CSR zaměřené na vnější prostř̌edí organizace zahrnují:

- firemní dárcovství finančního i materiálního charakteru (pomoc občanům po povodních, vybavení škol, dětských domovů...)

- firemní dobrovolnictví

- podpora projektů v oblasti kultury a sportu

- $\quad$ podpora projektů v oblasti sociální integrace potřebných skupin

- rozvoj zaměstnanosti a podpora místní infrastruktury

- $\quad$ podpora vzdělávání - spolupráce s mladými lidmi a studenty

Dotčenými zainteresovanými skupinami místní komunity vnějších sociálních aktivit jsou:

- místní samospráva

- školy

- instituce sociální péče

- zájmové neziskové organizace

- $\quad$ široká veřejnost

- jednotlivci

Společenská odpovědnost může být velmi dobrou konkurenční výhodou a to jak v oblasti vlastních lidských zdrojů nebo prríklonu zákaznické veřejnosti v důsledku vnímání prospěšnosti konání dané organizace na trhu.

Firmy by se kromě generování zisku měly angažovat také ve prospěch společnosti, ve které působí. Koncept CSR by se neměl týkat pouze velkých firem, ale měl by se stát výsadou celého podnikatelského sektoru.

\section{Analýza uplatňování sociálního pilíre CSR}

Fungování sociálního pilíre zahrnuje mnoho aktivit, které svým působením zahrnují aktivní uplatňovaní společenské odpovědnosti fïrem. Analýza byla provedena se zaměstnanci organizací se zaměřením na jejich vnímání důležitosti a uplatňování aktivit sociálního pilíre CSR zaměřené na vnitřní a vnější prostř̌edí v jednotlivých firmách.

Analýza byla prováděna prostřednictvím dotazníkového šetření. Počet doručených dotazníků je 124, z toho 21 (17\%) představují zaměstnanci malých firem do 25 zaměstnanců, 44 (35\%) zaměstnanci středních firem do 250 zaměstnanců a 59 (48 \%) zaměstnanci velkých firem nad 250 zaměstnanců. Přes $65 \%$ oslovených působí v podnicích více než 10 let, což značí, že většina respondentů dobře zná podnikové prostředí. $51 \% \mathrm{z}$ dotazovaných tvoří zaměstnance ve vrcholovém a středním managementu firem.

Osloveni jsou zaměstnanci firem působící na území České republiky. Obrázek 1 ukazuje procentuální podíl jednotlivých krajů České republiky. Je možno vidět, že nejvyšší podíl (47\%) respondentů pracuje v Moravskoslezském kraji, následuje Praha (11\%), kraj Vysočina a Jihomoravský kraj (7 \%). 
Obrázek 1: Procentuální podíl jednotlivých krajů ČR

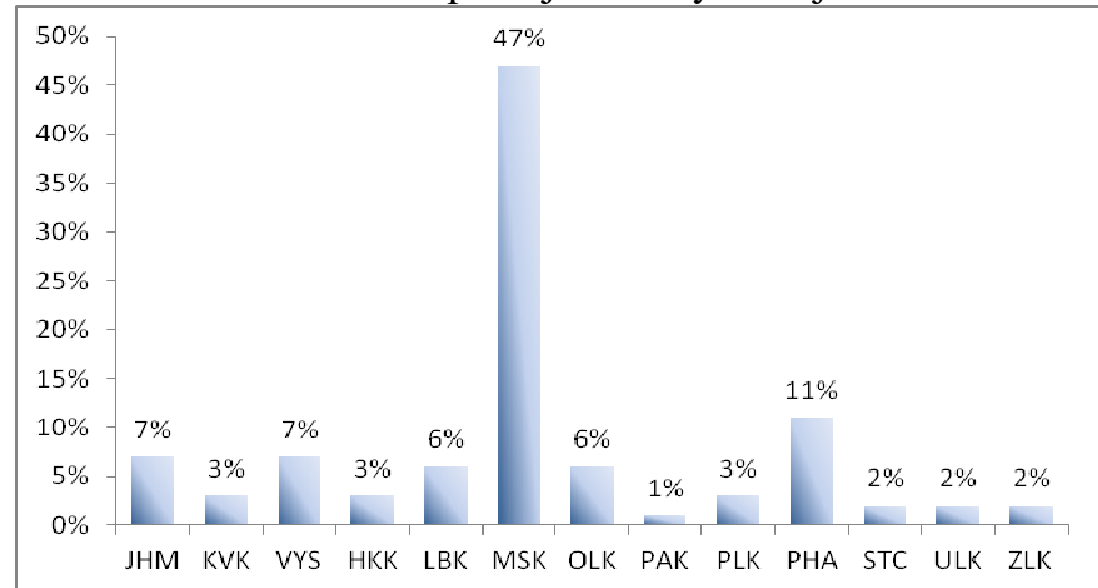

Zdroj: vlastní zpracování

První část dotazníku ukazuje uplatňování daných přístupů v podnicích. Druhá část se věnuje pohledu respondentů v praxi na sociální oblast společenské odpovědnosti firem.

Poskytování sociálních výhod - stravenky, pojištění, příspěvek na důchodové pojištění, poukázky na sport, kulturu, atd.

Obrázek 2: Míra poskytování sociálních výhod

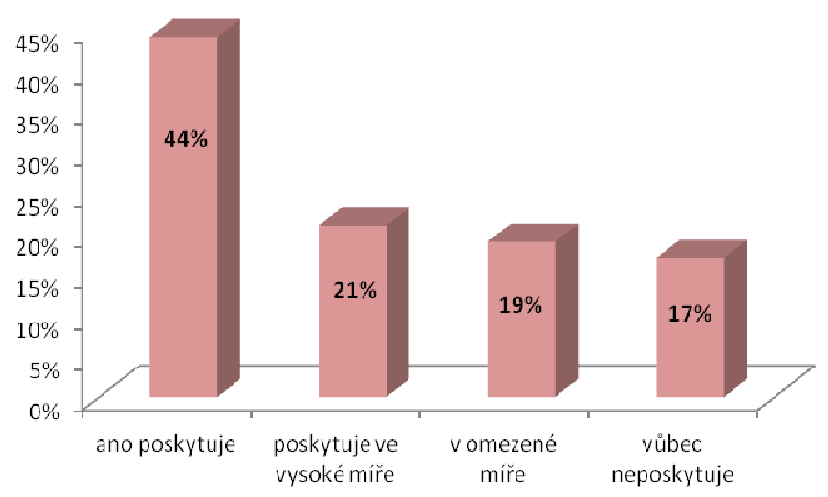

Zdroj: vlastní zpracování
Obrázek 3: Míra důležitosti poskytování sociálních výhod z pohledu respondentů

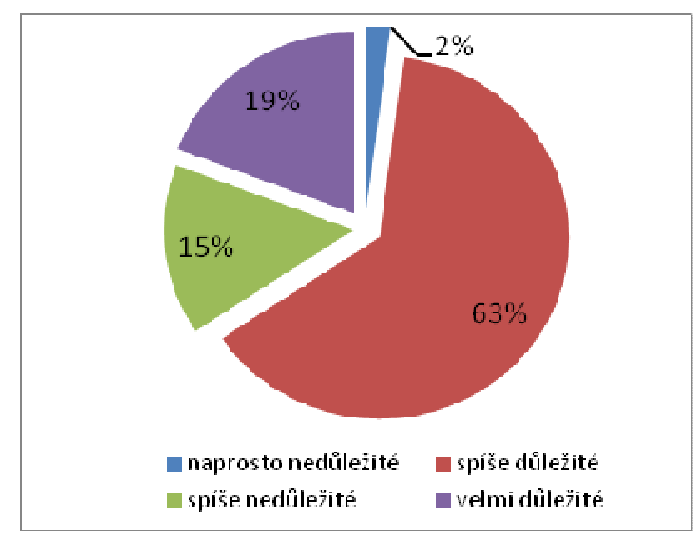

Zdroj: vlastní zpracování

Obrázek 2 ukazuje míru poskytování sociálních výhod organizacemi. 44 \% dotazovaných potvrzuje poskytování sociálních výhod. $21 \%$ z dotazovaných uvádí, že sociální výhody jsou poskytovány ve vysoké míře. Velký počet respondentů (49), kteří uvedli poskytování sociálních výhod ve vysoké míře, pracuje ve velké firmě s více než 250 zaměstnanci. Naopak respondenti pracující v malé firmě neuvedli ani jednou tuto možnost. Poskytování sociálních výhod v omezené mîre uvedlo $19 \%$ respondentů. Až $28 \%$ malých fïrem a $34 \%$ středních firem neposkytuje sociální výhody vůbec. Při zaměření na vnímání důležitosti poskytování sociálních výhod (obrázek 3), 82 \% respondentů je považuje za důležité.

Pracovní podmínky - nadstandardní pracovní podmínky, tzn. např. možnost využití firemní tělocvičny - hřiš̌tě, možnost krytého parkování kol, apod. 
Obrázek 4: Míra poskytování pracovních podmínek organizacemi
Obrázek 5: Míra důležitosti poskytování nadstandardních pracovních podmínek pro respondenty

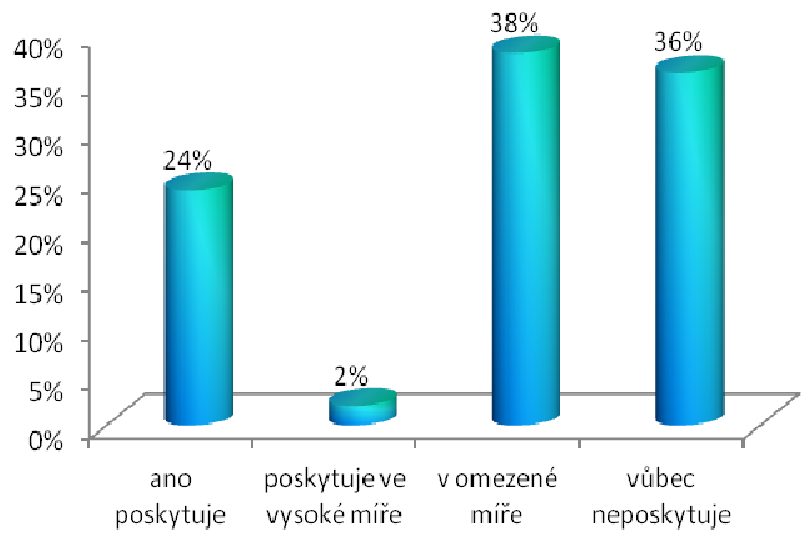

Zdroj: vlastní zpracování

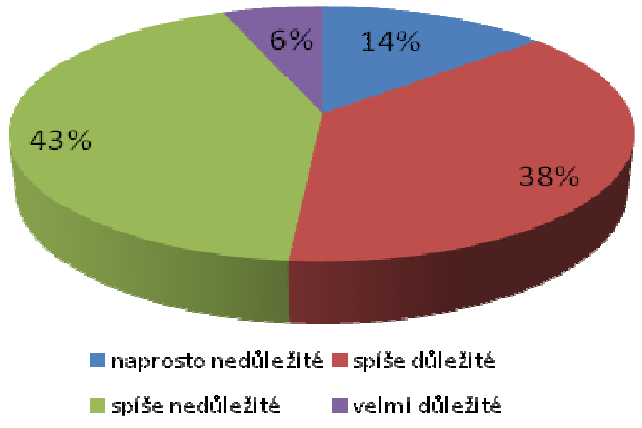

Zdroj: vlastní zpracování

Z obrázku 4 je patrné, že nadstandardní pracovní podmínky poskytují firmy zejména v omezené míre (38 \%). Jedná se zejména o velké firmy (28 firem). Naopak malé a střední firmy z většiny neposkytují nadstandardní pracovní podmínky vůbec. Poskytování nadstandardních pracovních podmínek není vnímáno respondenty jako důležité. Tento benefit není ve většině firem součástí firemní kultury a není ani považován za významný přínos. Obrázek 5 ukazuje nadpoloviční většinu odpovědí v souvislosti s nedůležitostí poskytování nadstandardních pracovních podmínek.

Mimopracovní akce - outdoorové akce, firemní setkání s rodinnými příslušníky, plesy, výjezd na kulturní představení, sportovní klání, apod.

Obrázek 6: Pořádání mimopracovních akcí organizacemi

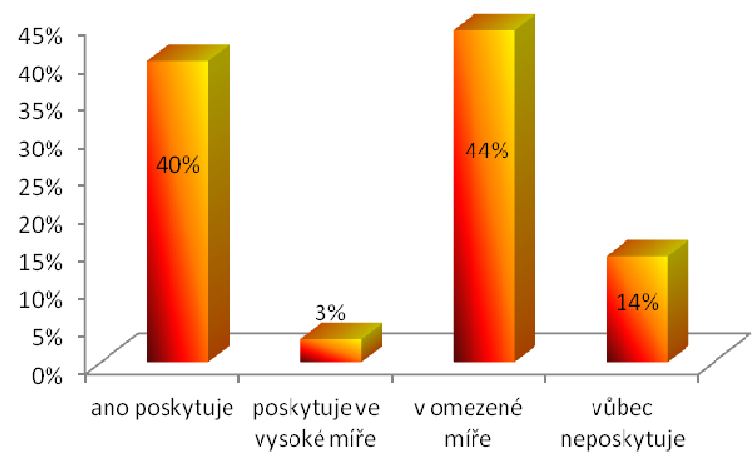

Zdroj: vlastní zpracování
Obrázek 7: Míra důležitosti pořádání mimopracovních akcí pro respondenty

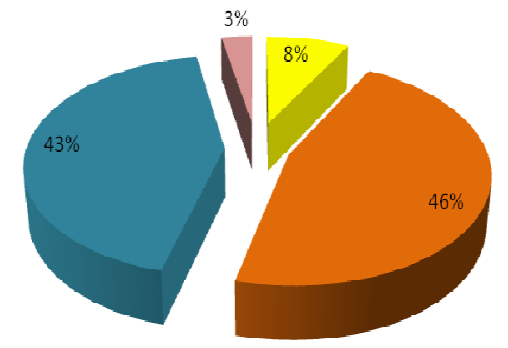

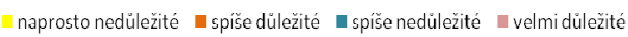

Zdroj: vlastní zpracování

Jak je možné vidět v obrázku 6, 87 \% firem poskytuje mimopracovní akce. Mimopracovní akce jsou zaměřeny prredevším k vytvoření otevřeného a vzájemně vstřícného pracovního prostředí, které podněcuje stmelení týmů a komunikaci mezi jeho členy. Nelze to však zcela považovat za společensky odpovědnou aktivitu, vzhledem $k$ důležitosti přikládané pracovníky 
(necelá polovina - viz obrázek 7). Firmy včleňují tyto aktivity do své firemní kultury především pro zvýšení efektivnosti pracovního týmů.

Možnost osobního růstu - návštěvy kongresů, konferencí, výstav, rotace ve firmě, umožnění dalšího studia, apod.

Obrázek 8: Možnosti osobního růstu poskytované organizacemi

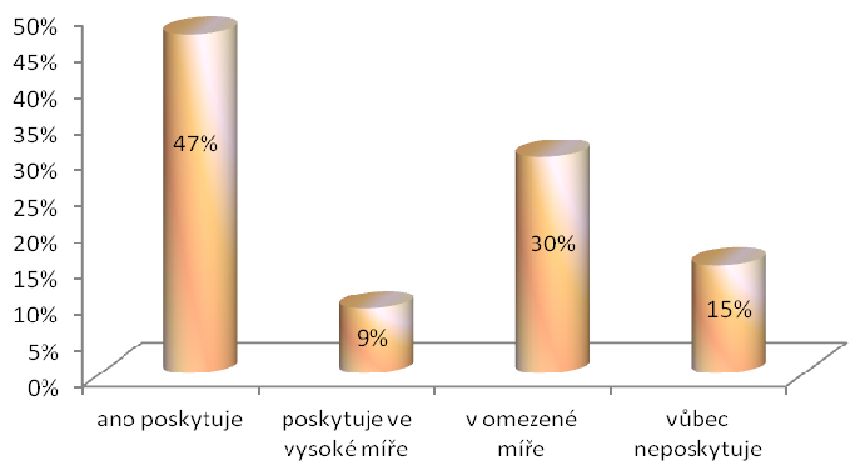

Zdroj: vlastní zpracování
Obrázek 9: Míra důležitosti poskytování možností osobního růstu pro respondenty

Obrázek 8 ukazuje poskytované možnosti osobního růstu zaměstnanců. Téměř $80 \%$ firem tyto aktivity umožňuje, což značí, že firmy se soustředí na osobní rozvoj zaměstnanců. Co se týče míry důležitosti pro dotazované (obrázek 9), lze vidět, že možnosti osobního růstu jsou velice žádané. Přes 90 \% dotazovaných považuje možnost osobního růstu za důležité. Pokud jsou tyto aktivity vhodně využívány, slouží jako stabilizační prvek klíčových zaměstnanců.

Vzdělávání v rámci firmy nad rámec zákona - kurzy, školení, tréninky, jazyková a PC průprava, apod.

Tato otázka je víceméně doplňující otázkou k předešlé. Jedná se o úzké propojení s osobním růstem.

Obrázek 10: Poskytování vzdělávání nad rámec zákona

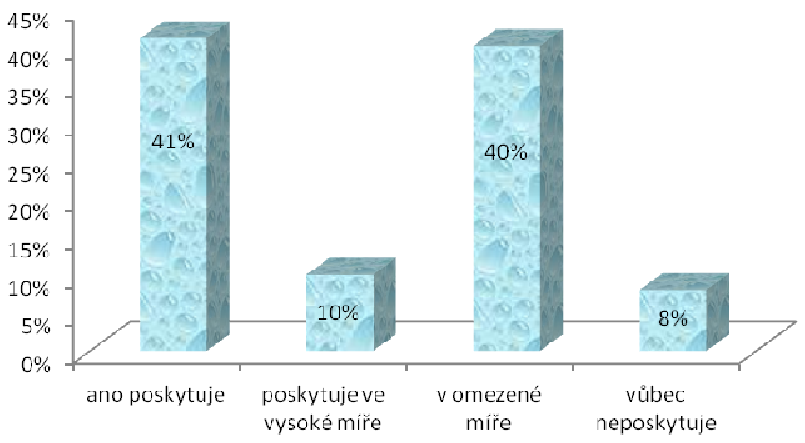

Zdroj: vlastní zpracování
Obrázek 11: Míra důležitosti poskytování vzdělávání nad rámec zákona pro respondenty

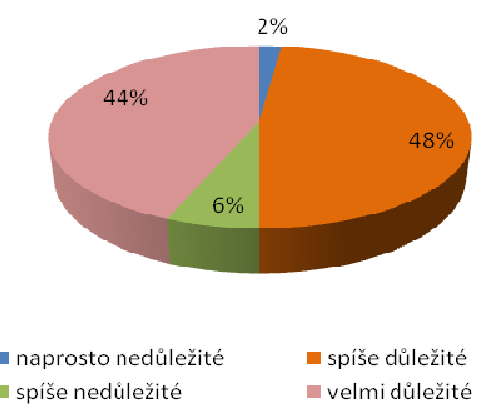

Zdroj: vlastní zpracování 
Vzdělávání zaměstnanců se řadí mezi nejběžnější aktivity zaměřené na osobní růst jedince společnosti. Především prostřednictvím vzdělávání (at’ už je uskutečňováno jakoukoliv formou, na pracovišti či mimo něj) se zhodnocuje lidský kapitál, získává znalosti, dovednosti a rozvíjí se, což přináší podniku značné výhody pro zaměstnavatele i zaměstnance. Vzdělávání poskytuje přes $80 \%$ firem, ve vysoké míře především velké firmy (50 firem). Malé firmy se soustředí zejména na vzdělávání pro zvýšení kompetencí pracovníků, velké firmy umožňují vzdělávání pracovníka i v oblastech zájmů pracovníků. Respondenti považují vzdělávání za důležitou oblast benefitů. Vzhledem k vysoké míre důležitosti (92\% - viz obrázek 11) může vzdělávání představovat i významný motivační faktor.

Spolupráce se studenty - umožnění praxe či stáží studentům, pomoc při tvorbě diplomových a disertačních prací, vyhlašování olympiád, apod.

Obrázek 12: Spolupráce organizací se studenty a mladými lidmi
Obrázek 13: Míra důležitosti spolupráce se studenty a mladými lidmi dle názorů respondentů

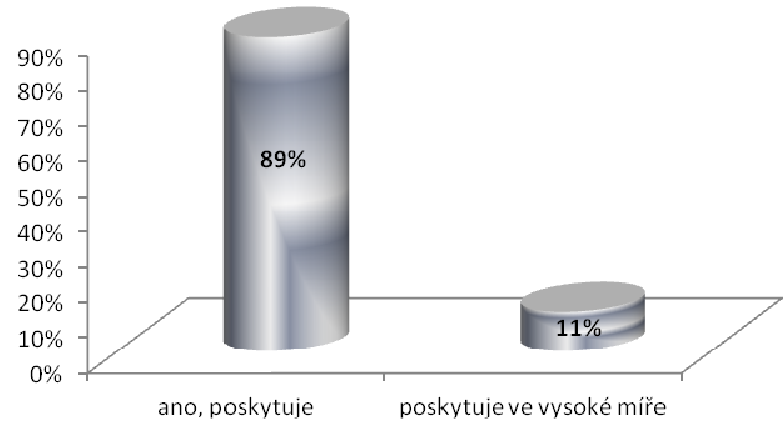

Zdroj: vlastní zpracování

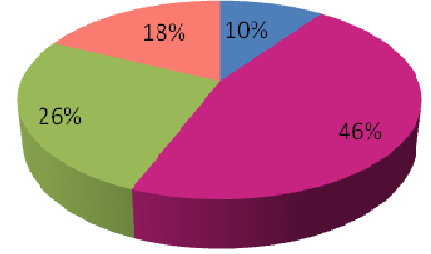

- naprosto nedůležité - spiše důležité 『 spiše nedúležité

Zdroj: vlastní zpracování

Spolupráce se studenty a mladými lidmi a míra důležitosti těchto aktivit je v jistém nesouladu. Respondenti uvádějí naprostou spolupráci firem s touto skupinou (viz obrázek 12), ovšem míra vnímané důležitosti se pohybuje okolo $60 \%$. Vysvětlením může být skutečnost, že spolupráce se studenty probíhá průřrezově v organizacích všech dotazovaných. Mnozí z dotazovaných, kteří nevidí tuto aktivitu jako prioritní, jsou ve skupinách pracovníků, kteří nemohou tuto aktivitu ovlivnit nebo pokud jsou ve vedoucích pozicích, neumožňují tuto spolupráci. I přesto byla tato aktivita hodnocena prŕíznivě.

Regionálně prospěšné akce - sponzorování plesů, akcí pro děti, podpora sportovních klubů či zvîrat v ZOO, spolupráce s domovem důchodců, apod. 
Obrázek 14: Organizování místně prospěšných akcí organizacemi

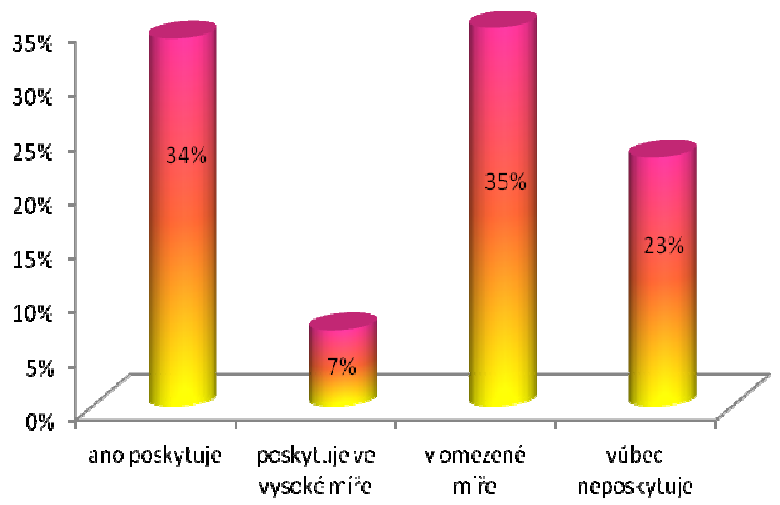

Zdroj: vlastní zpracování
Obrázek 15: Míra důležitosti organizování místně prospěšných akcí z pohledu respondentů

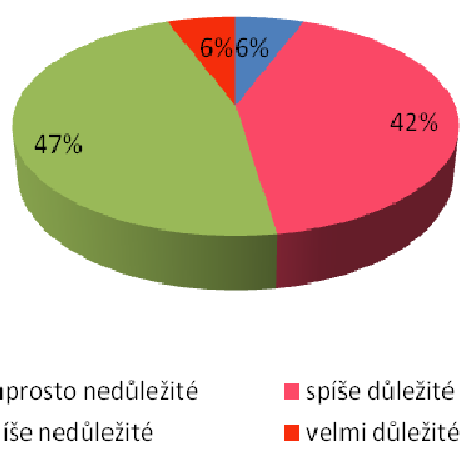

Zdroj: vlastní zpracování

Obrázek 14 ukazuje procentuální podíl poskytování místně prospěšných akcí. Téměř dvě třetiny dotázaných uvedlo, že jejich organizace tyto aktivity praktikují. Poskytování regionálně prospěšných akcí je však doménou zejména velkých firem. Malé a střední firmy je poskytují v omezené míře či vůbec. Avšak větší polovina respondentů nepovažuje realizaci těchto aktivit za důležitou (viz obrázek 15). Z výše uvedeného vyplývá, že většina respondentů pracuje $\mathrm{v}$ organizacích, kde je vysoká firemní kultura, nebot' místně prospěšné akce představují zároveň udržování dobrých vztahů s místní komunitou.

Péče o seniory - materiální či finanční podpora, organizace zájezdů, besed, setkání s bývalými kolegy, oslavy významných jubileí, apod.

Obrázek 16: Aktivity organizací související s péčí o seniory

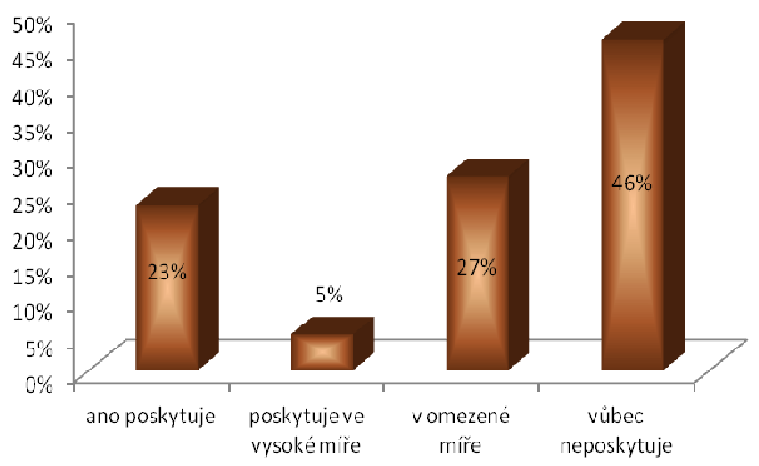

Zdroj: vlastní zpracování
Obrázek 17: Míra důležitosti aktivit organizací související s péčí o seniory $\mathrm{z}$ pohledu respondentů

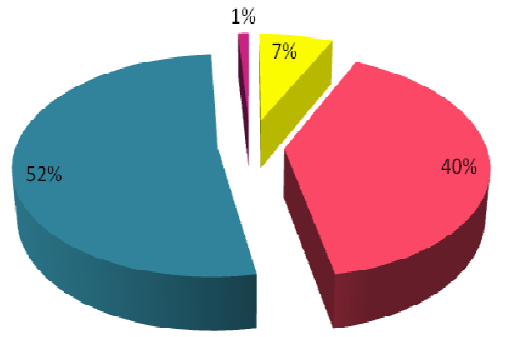

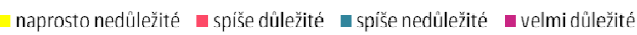

Zdroj: vlastní zpracování

Aktivity zaměřené na péči o seniory představují nejslabší formu uplatňování aktivit sociálního pilîre CSR. Téměř $50 \%$ organizací tyto aktivity vůbec neposkytuje (obrázek 16). Zbývající půlka firem je $z$ drtivé většiny tvořena velkými firmami. Ani $z$ pohledu důležitosti nepředstavuje tato aktivita výrazný zájem. 60 \% z dotazovaných nepovažuje aktivity spojené s péčí o seniory za důležité. 


\section{Komentář $k$ analýze uplatňování sociálního pilíře CSR}

Uplatňování sociálního pilîre v českých podmínkách se zaměřuje na vnější a vnitřní prostředí. Aktivity zaměřené na vnitřní prostředí představují např. uplatňování sociálních výhod, nadstandardní pracovní podmínky, mimopracovní akce, možnosti osobního rozvoje, vzdělávání nad rámec legislativní povinnosti. Co se týče uplatňování sociálních výhod, drtivá většina velkých firem tyto výhody poskytuje, a to i ve vysoké míre. Naopak malé a střední firmy poskytují tyto výhody v omezené míre. 34 \% středních firem je vůbec neposkytuje. Souvisí to zejména s finanční náročností těchto benefitů. Malé a střední firmy nemají tolik disponibilních zdrojů k poskytování sociálních výhod. Velké organizace mívají propracovaný systém poskytování sociálních výhod a považují je za významnou část odměňování pracovníků v podobě nemzdových složek. $82 \%$ dotazovaných považuje sociální výhody za důležité, $\mathrm{z}$ čehož lze usoudit důležitost těchto výhod v systému odměňování a také významnost společenské odpovědnosti podniků.

Nadstandardní pracovní podmínky nejsou v podmínkách českých podniků považovány za prríliš významné. Ani $\mathrm{z}$ pohledu zaměstnanců nepředstavují veliký přínos. Naopak mimopracovní akce využívá drtivá většina podniků - 87 \%. Jsou vhodnou formou, jak udržet či zvýšit pracovní efektivnost týmů, ovšem pracovníci nepřikládají těmto akcím př́lišnou důležitost. Je diskutabilní, zda existuje přímé propojení se společenskou odpovědností firem. Možnost osobního růstu je $\mathrm{v}$ dnešní době velice využívanou aktivitou společnostmi. Téměr̆ $80 \%$ firem podporuje osobní růst pracovníků, a to jak velké, tak střední i malé firmy. Zaměstnanci přikládají velkou důležitost možnosti osobního rozvoje. Firmy prostřednictvím této aktivity podporují rozvoj zaměstnanců, zhodnocují lidský kapitál, což pochopitelně zvyšuje hodnotu firmy a také konkurenceschopnost. Specifickou a zároveň hlavní aktivitou osobního růstu je vzdělávání zaměstnanců poskytované nad rámec zákona. Z analýzy vyplynula velká rozšířenost vzdělávání (80 \%), což představuje hlavní aktivitu v rámci osobního rozvoje pracovníků. Zaměstnanci přikládají vzdělávání vysoký význam a důležitost, nebot' dochází k zvyšování jejich hodnoty pro podnik či na trhu práce. Současně je nutné podotknout, že vliv globální ekonomické krize přinutil podniky omezit vzdělávání zaměstnanců $\mathrm{v}$ rámci úspor. Nicméně vzdělávání zaměstnanců nad rámec legislativní povinnosti je jedna $\mathrm{z}$ nejběžnějších aktivit sociálního pilî́re CSR zaměřených na vnitřní prostředí.

Mezi aktivity sociálního piliřre CSR pưsobících na vnější okolí se analýza zaměřuje na spolupráci se studenty a mladými lidmi, regionálně prospěšné akce a péči o seniory. Spolupráce se studenty a mladými lidmi probíhá ve všech organizacích, vnímání důležitosti této aktivity je z $60 \%$ pozitivní. Nesporný je ovšem fakt, že ne všechny organizace poskytují studentům potřebné interní informace. Spolupráce je přínosem zejména v podobě náhledu na fungování podnikatelského subjektu v praxi. Regionálně prospěšné akce vykonává téměř dvě třetiny firem, kde působí dotazovaní. Ovšem z pohledu míry důležitosti nebyla prokázána př́lišná oblíbenost těchto aktivit. Nadpoloviční většina dotazovaných nepovažuje tyto aktivity za důležité. Místně prospěšné akce mohou dopomoci k propagaci firmy a ukázat směr ostatním podnikatelským subjektům, jak vhodně pomáhat a stát se společensky odpovědnou organizací. Zejména velké podniky si uvědomují sílu těchto aktivit. Pouze velké firmy se také zaměřují na aktivity spojené s péčí o seniory. Ovšem tato aktivita není respondenty vnímána jako dủležitá. Podnikatelské subjekty by si měly uvědomit skutečnost, že demografický vývoj směřuje k postupnému stárnutí obyvatelstva, proto by měl být tento trend brán na zřetel. 


\section{Závěr}

Celkově lze říci, že se firmy snaží provádět aktivity sociálního pilíře CSR, zaměřené na vnitřní a vnější prostředí, vcelku efektivně. Z analýzy vyplynulo, že většina firem se zaměřuje především na možnost osobního růstu zaměstnanců, vzdělávání pracovníků. Z toho lze usoudit, že firmy vnímají důležitost lidského kapitálu. Uvědomují si, že rozvoj lidských zdrojů představuje jednu z klíčových oblastí nejen personální strategie firmy, ale také celkové strategie podniku. Nad rámec povinných legislativních požadavků poskytují vzdělávání pracovníkům, podporují jejich rozvoj a nebojí se investic do lidského kapitálu. Uplatňování aktivit společenské odpovědnosti v oblasti lidských zdrojů bude zcela jistě konkurenční výhodou, což si mnoho firem začíná uvědomovat a tyto aktivity realizovat. Firmy si také uvědomují, že pozitivní působení na vnější prostředí přináší své výsledky. Realizace místních prospěšných akcí není ničím neobvyklým. Zejména velké firmy se snaží $\mathrm{v}$ této oblasti pomáhat a zviditelňovat se.

$\mathrm{Na}$ druhou stranu ovšem nelze pominout fakt, že ekonomika je dosti silně ovlivněna celosvětovou ekonomickou krizí. Ekonomická krize ovlivňuje chování podnikatelských subjektů a to pochopitelně i ve vztahu ke společenské odpovědnosti. Omezení některých aktivit společenské odpovědnosti ovšem nesouvisí s nezájmem či popíráním těchto myšlenek, jde daleko více o „boj o vlastní přežití“ organizace. Proto dochází k přesouvání realizace společensky odpovědných aktivit na pozdější dobu nebo jejich dočasnému omezení.

Do budoucna je třeba i nadále věnovat zvýšenou péči vzdělávání zejména klíčových zaměstnanců. Zvyšování kvalifikace představuje velice významný faktor sociálního piliře. I přes negativní působení ekonomické krize se firmy musí zaměřovat na zhodnocení lidského kapitálu.

\section{Literatura:}

[1] Communication from the Commission to the European Parliament, the Council, the European Economic and Social Committee and the Committee of the Regions. Brusel: European Commission, 2011

[2] HERCIK, P. Společenská odpovédnost organizací v kontextu komplexní podnikové strategie. Dizertační práce Zlín: UTB, 2011.

[3] OSTŘÍŽEK, J. Public Private Partnership. Příležitost a výzva. Praha: C.H.Beck, 2007. 284 s. ISBN 978-80-7179-744-9.

[4] PAVLÍK, M., BĚLČÍK, M. Společenská odpovědnost organizace. CSR v praxi a jak s ním dál. Praha: Grada Publishing, 2010, 176 s. ISBN 978-80-247-3157-5.

[5] PETŘíKOVÁ, R., HOFBRUCKEROVÁ, Z. Společenská odpovědnost organizací. Ostrava: DTO CZ, 2008. 184 s. ISBN 978-80-02-02099-8.

[6] PETŘíKOVÁ, R. Lidé v procesech ř́zení (multikulturní dimenze podnikání). Praha: Professional Publishing, 2007. 215 s. ISBN 978-80-86946-28-3.

[7] POLAČKOVÁ, Z. Fundraisingové aktivity. Jak získat finanční prostředky od místní komunity. Praha: Portál, 2005. 119 s. ISBN 80-7178-694-2.

[8] PORVAZNÍK, J. Spoločenská zodpovednost' organizácií - Corporate social responsibility. Studijní texty. Bratislava: Ekonóm, 2008. 85 s. ISBN 978-80-225-2622-7.

[9] Společenská odpovědnost organizací. (CSR) - aplikace a hodnocení. Praha: Národní informační stř̌edisko podpory kvality, 2008. 123 s. ISBN 978-80-02-01989-3.

[10] Společenská odpovědnost firem - aplikace a hodnocení - podnikatelský sektor. Praha: Národní informační stř̌edisko podpory kvality, 2009. 116 s. ISBN 978-80-02-02205-3. 
JEL M120, M140

Ing. Zdenka Hofbruckerová

studentka doktorského studia

Obchodně podnikatelská fakulta v Karviné

Slezská univerzita v Opavě

Univerzitní nám. 1934/3, 73340 Karviná

z.hofbruckerova@dtocz.cz 